\title{
DNA BARCODING OF SMILIOGASTRINAE (TELEOSTEI: CYPRINIFORMES) OF BANGLADESH BASED ON CYTOCHROME C OXIDASE SUBUNIT I (COI) SEQUENCES
}

\author{
Md. Sagir Ahmed ${ }^{a^{*}}$, Nafisa Nawal Islam ${ }^{\mathrm{b}}$, JBM Aysha Akter ${ }^{\mathrm{a}}$ and Nusrat Jahan Sanzida ${ }^{\mathrm{a}}$ \\ aDepartment of Zoology, University of Dhaka, Dhaka 1000, Bangladesh \\ ${ }^{b}$ Department of Biotechnology and Genetic Engineering, Jahangirnagar University, Savar, Dhaka 1342, Bangladesh \\ *Corresponding author. Email: sagir@du.ac.bd
}

\author{
Article history \\ Received: 7 September 2020; \\ accepted: 29 July 202
}

Keywords:

Smiliogastrinae; Barbs;

COI; Cyprinidae; DNA

barcoding; Phylogeny

\begin{abstract}
This study aims to molecularly characterize the phylogenetic relationship of small barbs under the Subfamily Smiliogastrinae (Cypriniformes: Cyprinidae) in Bangladesh using a fragment of the mitochondrial gene cytochrome c oxidase subunit I (COI). Samples were collected from rivers, haors (a seasonal wetland), baors (an oxbow lake), beels (perennial waterbody), and floodplains. A total of eleven species under five genera were confirmed based on both morphological and molecular approaches. The average Kimura two-parameter (K2P) distances for intraspecies and interspecies were 0.0058 and 0.1538 , respectively. The mean GC content was markedly low $(44.03 \%)$ in the COI sequences of the smiliogastrin species compared to the mean AT content (55.97\%). In addition to the barcode-based species identification, phylogenetic relationships among the species were also explored. Phylogenetic (neighbor-joining, parsimony, and maximum likelihood) as well as species delimitation (ASAP and mPTP) analyses of all the eleven species revealed distinct clusters in concurrence with the taxonomic status of the species.
\end{abstract}

\section{INTRODUCTION}

The open inland waters of Bangladesh are rich in faunal diversity consisting of 253 species of fish (IUCN Bangladesh 2015). A group of small freshwater fish species of the subfamily Cyprininae sensu lato (Cypriniformes: Cyprinidae) are called Barbs (puntimachh in Bengali). These small fishes (length $<25 \mathrm{~cm}$ ) are an important source of animal protein, fatty acids, essential vitamins and minerals, and are mainly consumed by local people in rural areas (Roos et al. 2007). According to estimates, these barb species constitute about $16-19 \%$ of the total annual catch depending on water bodies (Haroon et al. 2002; Hossain et al. 2008). Some of the barb species viz., Systomus sarana (Hamilton, 1822), Puntius sophore (Hamilton, 1822) are used as potential aquaculture species (IUCN Bangladesh 2015).

These barbs are characterized by a moderately to deeply compressed body, varying from silvery to greenish silvery or reddish-brown in color (Talwar and Jhingran 1991; Banglapedia 2015). The presence of spots, blotches, bands on the body, and the presence of 4 or 2 barbels (or their absence) are the key identifying characters (Talwar and Jhingran 1991; Banglapedia 2015). However, for non-experts, it is difficult to taxonomically identify the species as some other species exhibit very similar morphological characteristics. The body length of the adults varies from $5 \mathrm{~cm}$ to about $20 \mathrm{~cm}$ (Talwar and Jhingran 1991) and they inhabit all types of fresh- water habitats including rivers, streams, haors (seasonal wetland), baors (oxbow lake), beels (perennial waterbody), and floodplains throughout the country (Rahman 2005; Siddiqui et al. 2007; Hossain et al. 2008; Mian et al. 2013; Ahmed et al. 2019, 2020). At least ten species of barbs under two genera Puntius (9 species) and Oreichthys (1 species) are described from Bangladesh (Siddiqui et al. 2007). The latest taxonomy classifies them under five genera: Pethia (5 species), Puntius (3 species), Systomus (1 species), Oreichthys (1 species) and Osteobrama. When revising the classification of cyprinine fishes, Yang et al. (2015) proposed to place small-sized barbs of Asia (Puntius and allies), including Osteobrama, in the Tribe Smiliogastrini under the subfamily Cyprininae. Later, based on the phylogenetic classification of the extant genera of fishes of the order Cypriniformes, Tan and Armbruster (2018) placed Puntius and allies in the subfamily Smiliogastrinae. In Bangladesh, there have been several studies done on the abundance and distribution of barbs in rivers, floodplains, and mountain streams in different regions (Haroon et al. 2002; Mian et al. 2013; Mohsin et al. 2013). Correct identification of barbs and regular monitoring for adulteration are highly important as these fish have both nutritional and ornamental value.

It is now well established that a specific fragment of the mitochondrial cytochrome $\mathrm{c}$ oxidase subunit I (COI) sequence (DNA barcodes) can be used as an alternative to the traditional species identification based on morpho- 
logical characters (Hebert et al. 2003; Frézal and Leblois 2008; Leray and Knowlton 2015). Besides, the reconstruction of phylogenetic trees based only on morphology is controversial due to the complex evolutionary changes in morphological and physiological characters. Analysis of molecular characters provides more insights into the specific patterns of differentiation among the isolated fish samples. However, the use of short-length single-locus markers such as COI has a shortcoming because these sequences represent the whole phylogenetic history only partially. More sophisticated species delimitation systems using multiple loci should be employed for a more accurate inference (Brower 2006; Rubinoff et al. 2006; Dasmahapatra et al. 2010; Dupuis et al. 2012; Fujita et al. 2012; Collins and Cruickshank 2013).

Despite their great significance, few studies have been done on the taxonomy, biology, and biodiversity of barbs in Bangladesh (Hossain et al. 2008; Mian et al. 2013; Mohsin et al. 2013; Ahmed et al. 2019). Hence, the present study was carried out to identify smiliogastin species based on morphometric and molecular approaches and to infer phylogenetic relationships among them.

\section{MATERIALS AND METHODS}

\section{Collection of samples}

The target species were collected from the Tanguar Haor, Sunamganj (25.1503 N 91.0603 E); Hakaluki haor, Moulvibazar (24.6767 N 92.0469 E); Sirajdikhan, Munshiganj (23.65 N 90.38 E); Padma, Rajshahi (24.35 N 88.65 E); Kuakata, Patuakhali (21.85 N 90.10 E); Dacope, Khulna (22.57 N 89.49 E); Sonargaon, Narayanganj (23.64 N 90.62 E); Boiddar Bazar Ghat, Sonargaon, Narayanganj (23.65 N 90.63 E); and Chalan Beel, Singra, Natore (24.5134 N 89.0539 E) during fishing expeditions from July 2015 to June 2018 (Figure 1). The samples in frozen condition were immediately transported to the DNA Barcoding Lab, Department of Zoology, University of Dhaka. At least 3-5 individuals per taxon were examined for the morphometric and meristic study except for Oreichthys cosuatis (Hamilton, 1822) and Pethia guganio (Hamilton, 1822), in which case, two individuals were analyzed to assess variability within the species. In this study, we used two-letter abbreviations, $P u$. and $P e$. for the genera Puntius and Pethia, and Or. and Os. for the genera Oreichthys and Osteobrama, respectively to avoid any ambiguity for the readers.

\section{Morphometric and meristic study}

All the collected specimens were fresh, having visually distinguishing characteristics (Table 1) and were identified in accordance with the reference materials (Rahman 2005; Talwar and Jhingran 1991). Morphometric characters were measured using Digital Callipers with an accuracy of $0.01 \mathrm{~mm}$, and the specimens were identified according to the previous taxonomic description following Rahman (2005) and Talwar and Jhingran (1991). Meristic characters were counted using standard methods. Body color, shape, spot, barbels, lateral line scales, fin formula, etc. were examined.

\section{DNA Extraction}

$20 \mathrm{mg}$ of muscle tissue was removed aseptically from each fish sample, just above the caudal fin. Total genomic DNA was obtained by addition of $500 \mu$ of TES buffer (0.05 M Tris-HCl, pH 8.0, 0.025 M EDTA, and $0.15 \mathrm{M} \mathrm{NaCl}$ ) and digestion with $15 \mu \mathrm{l}$ of proteinase-K $(20 \mathrm{mg} / \mathrm{ml})$. Incubation was carried out at $56^{\circ} \mathrm{C}$ for $12-18$ hours until the tissue was totally dissolved. Further steps in isolating genomic DNA were performed following the standard phenol-chloroform-isoamyl alcohol method described by Sambrook et al. (1989).

\section{Visualization and quantification of extracted DNA}

The quality of the isolated DNA was visualized in $1 \%$ agarose gel using fluorescence of ethidium bromide under UV light, by direct comparison with a

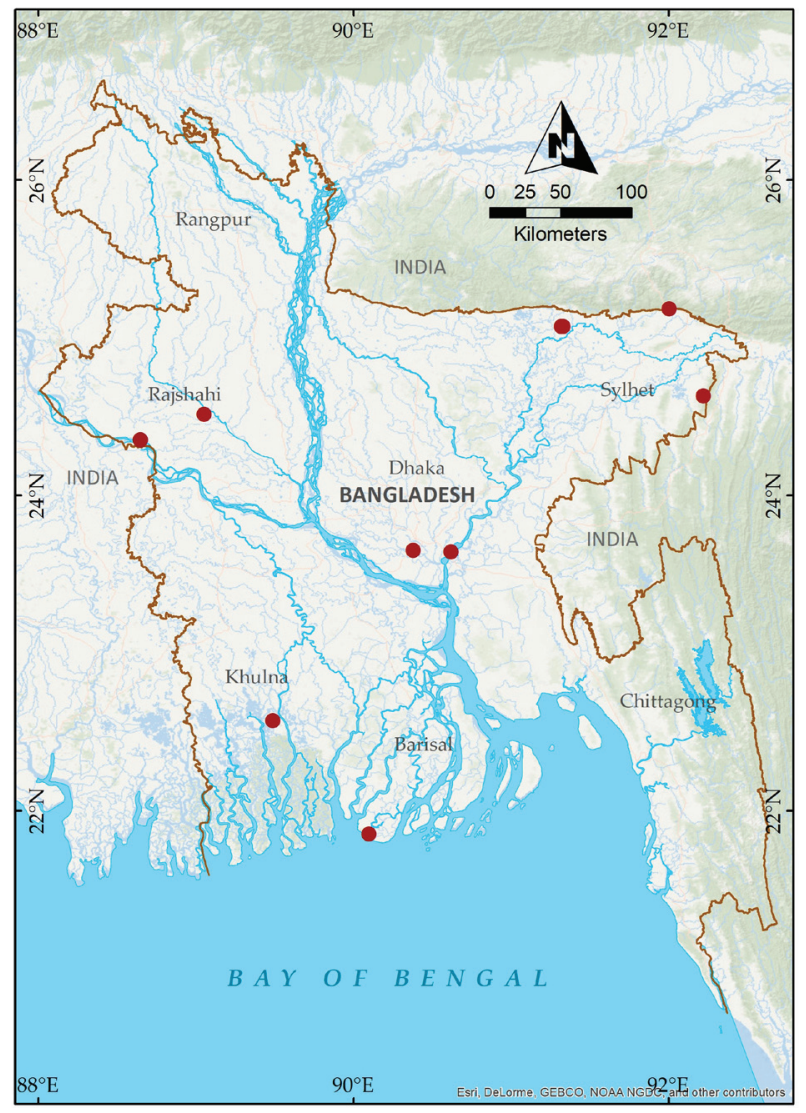

Figure 1. A map of the study area depicting the sampling location. 
Table 1. Morphometric and meristic characteristics of barb species along with their Red list status (Rahman 2005; Talwar and Jhingran 1991).

\begin{tabular}{|c|c|c|c|c|c|}
\hline Species & $\begin{array}{l}\text { Lateral line and } \\
\text { no. of scales }\end{array}$ & $\begin{array}{l}\text { No. of } \\
\text { barbel }\end{array}$ & Dorsal spine and rays & Spots on body & $\begin{array}{l}\text { IUCN red } \\
\text { list status } \\
\text { (Bangladesh } \\
\text { 2015) }\end{array}$ \\
\hline Putius sophore & $\begin{array}{l}\text { Complete } \\
24-26\end{array}$ & No barbel & $\begin{array}{l}\text { Last unbranched dorsal } \\
\text { ray ossificated and } \\
\text { smooth }\end{array}$ & $\begin{array}{l}\text { Two black blotches; at base of } \\
\text { dorsal rays and base of caudal fin }\end{array}$ & $\mathrm{LC}$ \\
\hline P. chola & $\begin{array}{l}\text { Complete } \\
24-26\end{array}$ & 2 & $\begin{array}{l}\text { Last unbranched dorsal } \\
\text { ray ossificated, strong } \\
\text { and smooth }\end{array}$ & $\begin{array}{l}\text { Two conspicuous dark blotches; at } \\
\text { the base of } 2 \text { nd- } 5 \text { th dorsal rays and } \\
\text { near base of caudal fin }\end{array}$ & $\mathrm{LC}$ \\
\hline P. terio & $\begin{array}{l}\text { Incomplete } \\
22-23\end{array}$ & No barbel & $\begin{array}{l}\text { Last unbranched dorsal } \\
\text { ray ossificated, strong } \\
\text { and smooth }\end{array}$ & $\begin{array}{l}\text { A black blotch over anal fin, from } \\
\text { which a fine dark line runs back to } \\
\text { base of caudal fin; a reddish orange } \\
\text { spot on operculum }\end{array}$ & $\mathrm{LC}$ \\
\hline Pethia conchonius & $\begin{array}{l}\text { Incomplete } \\
24-28\end{array}$ & No barbel & $\begin{array}{l}\text { Last unbranched dorsal } \\
\text { ray ossificated and } \\
\text { strongly denticulated } \\
\text { along the posterior edge }\end{array}$ & $\begin{array}{l}\text { Large black spot over posterior } \\
\text { portion of anal fin, A band of black } \\
\text { marks along the middle dorsal rays } \\
\text { during breeding season }\end{array}$ & $\mathrm{LC}$ \\
\hline P. ticto & $\begin{array}{l}\text { Incomplete } \\
23-26\end{array}$ & No barbel & $\begin{array}{l}\text { Last unbranched dorsal } \\
\text { ray ossificated, fairly } \\
\text { strong and serrated at its } \\
\text { posterior edge }\end{array}$ & $\begin{array}{l}\text { A block spot at commencement of } \\
\text { lateral line, another at sides of the } \\
\text { tail above anal fin. }\end{array}$ & VU \\
\hline P. gelius & $\begin{array}{l}\text { Incomplete } \\
22-23\end{array}$ & No barbel & $\begin{array}{l}\text { Last unbranched dorsal } \\
\text { ray ossificated, strong } \\
\text { and serrated }\end{array}$ & $\begin{array}{l}\text { A dark band over tail. Anterior } \\
\text { base of dorsal, pelvic and anal with } \\
\text { black mark }\end{array}$ & NT \\
\hline P. phutunio & $\begin{array}{l}\text { Incomplete } \\
21-23\end{array}$ & No barbel & $\begin{array}{l}\text { Last unbranched dorsal } \\
\text { ray ossificated, strong } \\
\text { and serrated }\end{array}$ & $\begin{array}{l}\text { Five steel-blue transverse bars } \\
\text { which fade into three black } \\
\text { blotches, } 1 \text { st behind operculum, } \\
2^{\text {nd }} \text { above anal fin and } 3^{\text {rd }} \text { on caudal } \\
\text { peduncle }\end{array}$ & $\mathrm{LC}$ \\
\hline P. guganio & Incomplete 36 & No barbel & $\begin{array}{l}\text { Last unbranched dorsal } \\
\text { ray ossificated, strongly } \\
\text { denticulated along the } \\
\text { posterior edge }\end{array}$ & $\begin{array}{l}\text { A light greenish silvery lateral } \\
\text { band }\end{array}$ & $\mathrm{LC}$ \\
\hline Systomus sarana & $\begin{array}{l}\text { Complete } \\
32-34\end{array}$ & 4 & $\begin{array}{l}\text { Last unbranched dorsal } \\
\text { ray strongly ossificated } \\
\text { and finely serrated along } \\
\text { its posterior edge }\end{array}$ & $\begin{array}{l}\text { No spot, body silvery, darker on } \\
\text { the back }\end{array}$ & NT \\
\hline $\begin{array}{l}\text { Oreichthys } \\
\text { cosuatis }\end{array}$ & $\begin{array}{l}\text { Interrupted } \\
22-23\end{array}$ & No barbel & $\begin{array}{l}\text { Last unbranched dorsal } \\
\text { ray weak, non-ossificated } \\
\text { and smooth }\end{array}$ & $\begin{array}{l}\text { Absence of a spot on the caudal- } \\
\text { fin base, a bright-yellow dorsal fin } \\
\text { with a large black mark covering } \\
\text { the distal margin of the dorsal fin, } \\
\text { and red ventral fins, and a black } \\
\text { spot in the anal fin }\end{array}$ & EN \\
\hline Osteobrama cotio & $\begin{array}{l}\text { Complete } \\
60-65\end{array}$ & No barbel & $\begin{array}{l}\text { Dorsal with weak and } \\
\text { serrated ossificated ray }\end{array}$ & $\begin{array}{l}\text { Scales on upper half of the body } \\
\text { with minute black dots. A black } \\
\text { spot at commencement of dorsal, } \\
\text { another over nape. Silvery, fins } \\
\text { yellowish. }\end{array}$ & NT \\
\hline
\end{tabular}

CR - Critically Endangered; EN - Endangered; VU - Vulnerable; NT - Near Threatened; LC - Least Concern; and DD - Data Deficient. 
standard marker (GeneRuler $1 \mathrm{~kb}$ Plus DNA ladder, $0.1 \mu \mathrm{g} / \mu \mathrm{L}$, Catalogue number: SM1333, Thermo Scientific). The fluorescence was documented using AlphaImager ${ }^{\circledR}$ gel documentation systems (ProteinSimple, USA). For the quantification of the extracted DNA, UV-spectrophotometry (NanoDrop 2000) was used to infer the concentration of DNA $(n g / \mu \mathrm{L})$ at the absorption of $260 \mathrm{~nm}(\mathrm{OD})$. Additionally, the quality of the isolated DNA was assessed using $\mathrm{OD}_{260} / \mathrm{OD}_{280}$ (Down and Wilfinger 1983).

\section{PCR amplification}

For PCR amplification of the mitochondrial COI gene, we used primers FishF1 (5'TCAACCAACCACAAAGACATTGGCAC-3') and FishR1 (5'-TAGACTTCTGGGTGGCCAAAGAA TCA-3') (Ward et al. 2005). The final volume of each PCR was $25 \mu 1$ and consisted of $12.5 \mu 1$ of $\mathrm{GoTaq}^{\circledR} \mathrm{G} 2$ Hot Start Colorless Master mix (Promega, Madison, WI USA), $1 \mu$ of each primer $(0.01 \mathrm{mM}), 8.5 \mu$ l of nucleasefree water, and $2 \mu \mathrm{l}$ of DNA template. Amplifications were performed using a Veriti ${ }^{\mathrm{TM}}$ 96-Well Thermal Cycler (Applied Biosystems, Inc.). The thermocycling profile consisted of initial denaturation at $95^{\circ} \mathrm{C}$ for $2 \mathrm{~min}, 30$ cycles of denaturation at $95^{\circ} \mathrm{C}$ for $30 \mathrm{~s}$, annealing at $52-54^{\circ} \mathrm{C}$ for $30 \mathrm{~s}$, and extension at $72^{\circ} \mathrm{C}$ for $1 \mathrm{~min}$, with a final extension at $72^{\circ} \mathrm{C}$ for $7 \mathrm{~min}$. PCR products were visualized on a $1 \%$ agarose gel using a standard mini-horizontal Agarose Gel Electrophoresis System (Catalogue No. MGU-602T, CBS Scientific, Inc.).

\section{Sequencing}

Bidirectional sequencing was performed using BigDye ${ }^{\circledR}$ Terminator version 3.1 cycle sequencing kit chemistry (Applied Biosystems Inc., USA) on an ABI 3730XL capillary sequencer by First BASE Laboratories Sdn Bhd, Malaysia. Sequences of both strands were assembled using Sequence Assembly Program CAP3 (Huang and Madan 1999). The bidirectional sequences were subsequently aligned using the MUSCLE 3.8.31 (Edgar 2010). The generated sequences were deposited with the NCBI GenBank (GB) and were accordingly assigned GB Accession Numbers (KX455895-96, KX455909, KY124379-80, KT353106, KT364771-73, KT76235960, MH087036, MK988520, MK988542, MN013419, MN083131, MN171353-54, MN171373, MN200455, MN200463-65, MN200473).

\section{Species delimitation and Molecular phylogenetic} analysis

Pairwise sequence comparisons of the set of COI gene sequences were performed using the K2P model (Kimura 1980). The amount of the nucleotide variation was determined after alignment and trimming gaps from both ends using the software MEGA version X (Kumar et al. 2018). For evaluation of the maximum-likelihood (ML) estimate of Transition/Transversion Bias, the substitution pattern and rates were estimated according to the $\mathrm{K} 2 \mathrm{P}$ model $(+\mathrm{G}+\mathrm{I})$. Then, to test whether the genes had reached the substitution saturation plateau, the COI gene sequence substitution saturation was investigated by plotting the number of transitions and transversions against pairwise genetic divergence using DAMBE (Data Analysis in Molecular Biology and Evolution) version 6.0 (Xia, 2017).

Phylogenetic and molecular evolutionary analysis was conducted using MEGA version X (Kumar et al. 2018). Best-fitting substitution models were selected according to the Bayesian information criterion (BIC). For molecular phylogenetic analysis by ML reconstruction, evolutionary relationships were inferred based on the Hasegawa-Kishino-Yano model (Hasegawa et al. 1985) with 1000 bootstrap replicates. A total of 26 sequences belonging to six genera and 11 species were randomly included in the study as ingroups from the GenBank (GB accession nos. and Country of origin listed in Supplementary Table 2). As outgroups, Esomus danricus from the tribe Cyprinini of the same subfamily and Psilorhynchus sucatio from the family Psilorhynchidae of the same order were selected. In addition, a neighborjoining (NJ) tree of K2P-distances (Tamura et al. 2004) and a maximum-parsimony (MP) tree were created using the Subtree-Pruning-Regrafting algorithm (Nei and Kumar 2000) with 1000 replications for bootstrap analysis to assess the phylogenetic relationships among species.

Species delimitation was performed using the Kimura K80 (ts/tv 2.0) substitution model of the software Assemble Species by Automatic Partitioning (ASAP) (https://bioinfo.mnhn.fr/abi/public/asap/) with the default parameters (i.e., recursive split probability of 0.01 ), since it rapidly offers a full graphical exploratory interface relevant species hypothesis (Puillandre et al. 2020). We also conducted a multi-rate Poisson Tree Processes (mPTP) analysis (https://mcmc-mptp.h-its. org $/ \mathrm{mcmc} /$ ) using the ML-generated tree, keeping all the parameters default (Kapli et al. 2017).

\section{RESULTS AND DISCUSSION}

\section{Species diversity and status}

A total of eleven species of freshwater barbs belonging to five genera; Pethia (5 species), Puntius (3 species), Systomus (1 species), Oreichthys (1 species) and Osteobrama (1 species) under the subfamily Smiliogastrinae were confirmed based on morphometric and meristic 
characteristics. Among them, Pe. ticto and Pu. terio were confusing, as their descriptions and photographs provided in the published books were contradictory (Rahman 2005; Siddiqui et al. 2007). As such, we considered the description provided by Talwar and Jhingran (1991). According to IUCN Red Book (IUCN Bangladesh 2015), out of these eleven smiliogastrins, six species were ranked as least-concern (LC), three near threatened (NT), one as vulnerable (VU), and one as endangered (EN) (Table 1).

\section{Molecular characterization, compositional bias, and saturation}

A total of $24 \mathrm{COI}$ sequences belonging to six genera and 11 species were generated. The BLAST analysis of each of our sequences (around 636 nucleotides, coding for 212 amino acids in length) revealed that they have $97-100 \%$ similarity with the pre-existing sequences of barb species in the NCBI database. Among the 557 nucleotide sites that we included in the final sequence alignment, 186 (33.39\%) were variable, 371 (66.61\%) were conserved, and $172(30.88 \%)$ were parsimonyinformative. The mean base composition in COI sequences of the Smiliogastrinae species showed a markedly low $\mathrm{G}$ content $(17.46 \pm 1.12 \%)$ compared to that of A, T, and C $(27.04 \pm 1.01 \%, 28.93 \pm 0.55 \%$, and $26.57 \pm 0.66 \%$, respectively) (Supplementary Table 1 ). Thus, the mean base composition in COI sequences of the species showed a lower average GC content (44.03 $\pm 1.50 \%)$ than the average AT content $(55.97 \pm 1.50 \%)$. To be specific, the average GC content of the three codon positions was $57.46 \pm 1.08 \%, 42.77 \pm 0.47 \%$, and 31.90 $\pm 3.77 \%$, respectively (Figure 2), indicating a significant decrease in the second and third codon positions compared to that of the first codon position, which reflects the pattern of AT and GC content observed in small

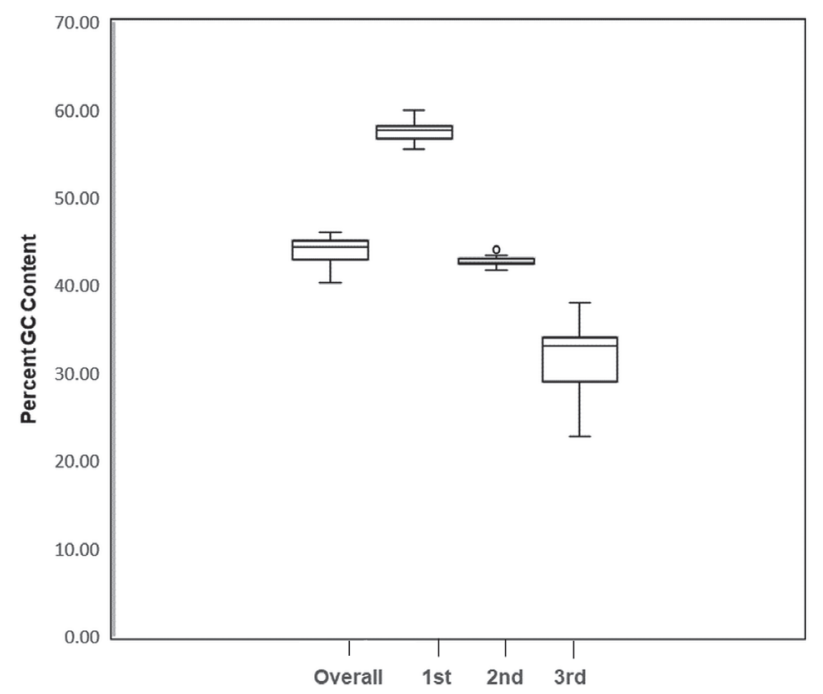

Figure 2. GC content ( $\%$ ) in different codon positions in the sequenced COI region of Smiliogastrinae fishes. indigenous fish species (SIS) of Bangladesh (Ahmed et al. 2019).

While working on cytochrome b gene of barbs, Tsigenopoulos and Berrebi (2000) reported that G was under-represented in the second and, particularly, in the third codon position ( $13 \%$ and $6.1 \%$, respectively), but there was no such bias found in the first codon position. In our analysis, significant compositional biases were found to exist in the second and third codon positions of the COI gene, where the $\mathrm{G}$ content $(14.22 \%$ and $7.00 \%$, respectively) was noticeably low compared to $31.20 \%$ in the first codon position. However, the composition of the rest of the bases exhibited heterogeneity in all codon positions throughout the species in our study. For example, there was an underrepresentation of $\mathrm{T}$ $(18.41 \%)$ in the first codon position, whereas $\mathrm{T}$ overrepresentation $(41.61 \%)$ occurred in the second codon position. Such reverse representation was also observed for $\mathrm{A}$ in the second $(15.62 \%)$ and third $(41.34 \%)$ positions of the codons.

The Transition/Transversion bias $(R)$ was estimated to be 3.58. Next, the substitution saturation analysis using DAMBE clearly depicted the linear increase of both transitions (s) and transversions (v) along with the no. of transitions exceeding the no. of transversions (Figure 3). This indicates that the COI gene sequences were well under the saturation threshold level, and therefore, the data still retained an ample phylogenetic signal for the estimation of true genetic distances.

In our study, all the species exhibited unique barcodes distinguishable from each other, and all individuals within a species and genus could be discriminated. The number of base substitutions per site from averaging over all sequence pairs between groups is shown in Table 2. The interspecies mean genetic divergence was 0.1538 , while the mean intraspecies divergence was only 0.0058 , indicating a high DNA barcoding gap. Therefore, there is no overlap in the range of intra- and interspecific COI sequence divergence of smiliogastrins. However, the presence of only a single sequence for 4 out of the 11 analyzed species is a limiting factor for obtaining any information about intraspecific variability.

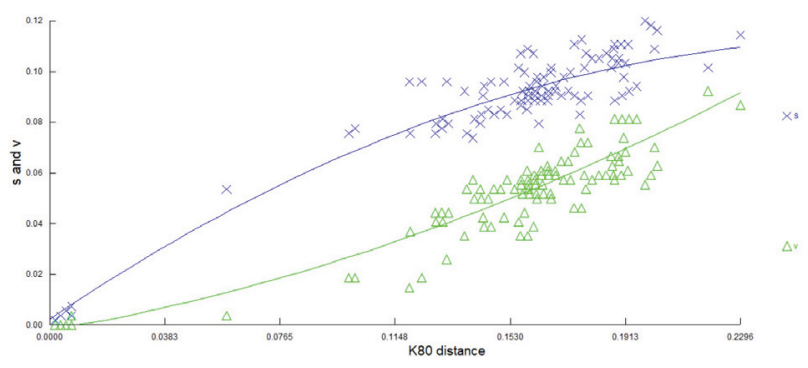

Figure 3. Transition (S) and transversion (V) values plotted against the K80 distance for COI gene of smiliogastrins. 
Table 2. Estimates of evolutionary divergence over sequence pairs between groups using the K2P model.

\begin{tabular}{|c|c|c|c|c|c|c|c|c|c|c|c|}
\hline & $\begin{array}{c}P e . \\
\text { conchonius }\end{array}$ & $\begin{array}{c}\text { Pe. } \\
\text { phutunio }\end{array}$ & $\begin{array}{l}\text { Pe. } \\
\text { gelius }\end{array}$ & $\begin{array}{c}\text { Pu. } \\
\text { sophore }\end{array}$ & Pu. chola & Pu. terio & $\begin{array}{c}\text { Or. } \\
\text { cosuatis }\end{array}$ & S. sarana & $\begin{array}{c}\text { Pe. } \\
\text { guganio }\end{array}$ & Pe. ticto & Os. cotio \\
\hline \multicolumn{12}{|l|}{$\begin{array}{l}\text { Pe. } \\
\text { conchonius }\end{array}$} \\
\hline $\begin{array}{l}\text { Pe. } \\
\text { phutunio }\end{array}$ & 0.127 & & & & & & & & & & \\
\hline Pe.gelius & 0.156 & 0.176 & & & & & & & & & \\
\hline $\begin{array}{l}\text { Pu. } \\
\text { sophore }\end{array}$ & 0.184 & 0.164 & 0.158 & & & & & & & & \\
\hline Pu. chola & 0.166 & 0.189 & 0.159 & 0.116 & & & & & & & \\
\hline Pu. terio & 0.188 & 0.200 & 0.192 & 0.118 & 0.124 & & & & & & \\
\hline $\begin{array}{l}\text { Or. } \\
\text { cosuatis }\end{array}$ & 0.201 & 0.219 & 0.195 & 0.181 & 0.202 & 0.202 & & & & & \\
\hline S. sarana & 0.164 & 0.174 & 0.157 & 0.144 & 0.164 & 0.152 & 0.178 & & & & \\
\hline $\begin{array}{l}\text { Pe. } \\
\text { guganio }\end{array}$ & 0.172 & 0.175 & 0.150 & 0.181 & 0.171 & 0.172 & 0.227 & 0.157 & & & \\
\hline Pe. ticto & 0.101 & 0.118 & 0.161 & 0.161 & 0.166 & 0.169 & 0.175 & 0.140 & 0.146 & & \\
\hline Os. cotio & 0.151 & 0.186 & 0.181 & 0.144 & 0.151 & 0.161 & 0.188 & 0.151 & 0.187 & 0.162 & \\
\hline
\end{tabular}

All ambiguous positions were removed for each sequence pair (pairwise deletion option). There was a total of 675 positions in the final dataset.

\section{Species delimitation and molecular phylogenetic} analysis

When we subjected the sequences to ASAP to build species partitions from single-locus sequence alignments, we generally found a good agreement between molecular operational taxonomic units (MOTUs) and morphological species, except for two taxa (Os. cotio and Or. cosuatis), which split into two well-differentiated clades (Figure 4). Thus, among the ten best ASAP partitions, 13 groups were identified based on the two lowest ASAP scores (partitions ranked first and second). For the partition with the "best" ASAP-score (2.50), the Proba (probability that the partition at step $\mathrm{n}$ is different from the partition at step n-1) and the barcode gap width were found to be $1.389759 \mathrm{e}-03$ and $7.93 \mathrm{e}-03$, respectively.

Although mPTP has been suggested to underperform consistently when there is a small number of species, and quite well when the number of species exceeds or is equal to 50 (Puillandre et al. 2020), our mPTP analysis was in congruence with the ASAP analysis, identifying 13 groups (Figure 4). Although Os. cotio specimens reported in our study were morphologically indistinguishable when we first identified them after their collection in 2015, both species delimitation analyses implied that one of them (Accession no. KT762359.1), placed as a distinct lineage separated from all the other Os. cotio, can be $O$ s. cotio sensu lato.

The phylogenetic analyses of smiliogastrins using ML, NJ, and MP methods revealed similar clades in concordance with the taxonomic status of the eleven species under five genera (Figure 4). The ML tree distinctly formed seven lineages for the five genera:
Puntius, Systomus, Oreichthys, Osteobrama, Pe. gelius, $P e$ guganio, and the remaining Pethia spp. Considering the nodes supported by more than $70 \%$ of bootstrap replicates as robust in accordance with previous reports (Hillis and Bull 1993; Lecointre et al. 1994; Zharkikh and Li 1992), in our study, the three Puntius spp. form a well-supported clade, but with unclear relationships among its three species. However, this might change if other species were included in the analysis. As indicated by the low support in branching, Pethia spp. are weakly supported as monophyletic. Even though the relationship between the species Pe. conchonius and Pe. ticto was weakly supported by $54 \%$ bootstrap value, our tree indicated them to be sister taxa. Although no support exists, $S$. sarana and Os. cotio could be in a sister position to Or. cosuatis in the tree.

Based on the presented data, Or. cosuatis have diverged separately at an early stage of evolution from one ingroup Oreichthys sp. reported from India (Figure 4). BLAST results showed $100 \%$ sequence similarity with the whole mitochondrial genome of Or. crenuchoides (GB AP012064.1) sequenced from Japan and 90.98\% similarity with Or. parvus (GB JF915631.1) sequenced from Singapore, rather than Or. cosuatis. Therefore, we presume that this entry (GB FJ459528) might be a cryptic species and needs taxonomic revision. Otherwise, to confirm that the two distinct haplotypes have occurred due to the adaptation to different geographical distribution, a more comprehensive study, involving a larger sample size, has to be carried out.

Similarly, it is evident from our phylogenetic tree that the Os. cotio collected from Tanguar Haor is genetically divergent (pairwise $p$-distances 0.056 ) from the other 


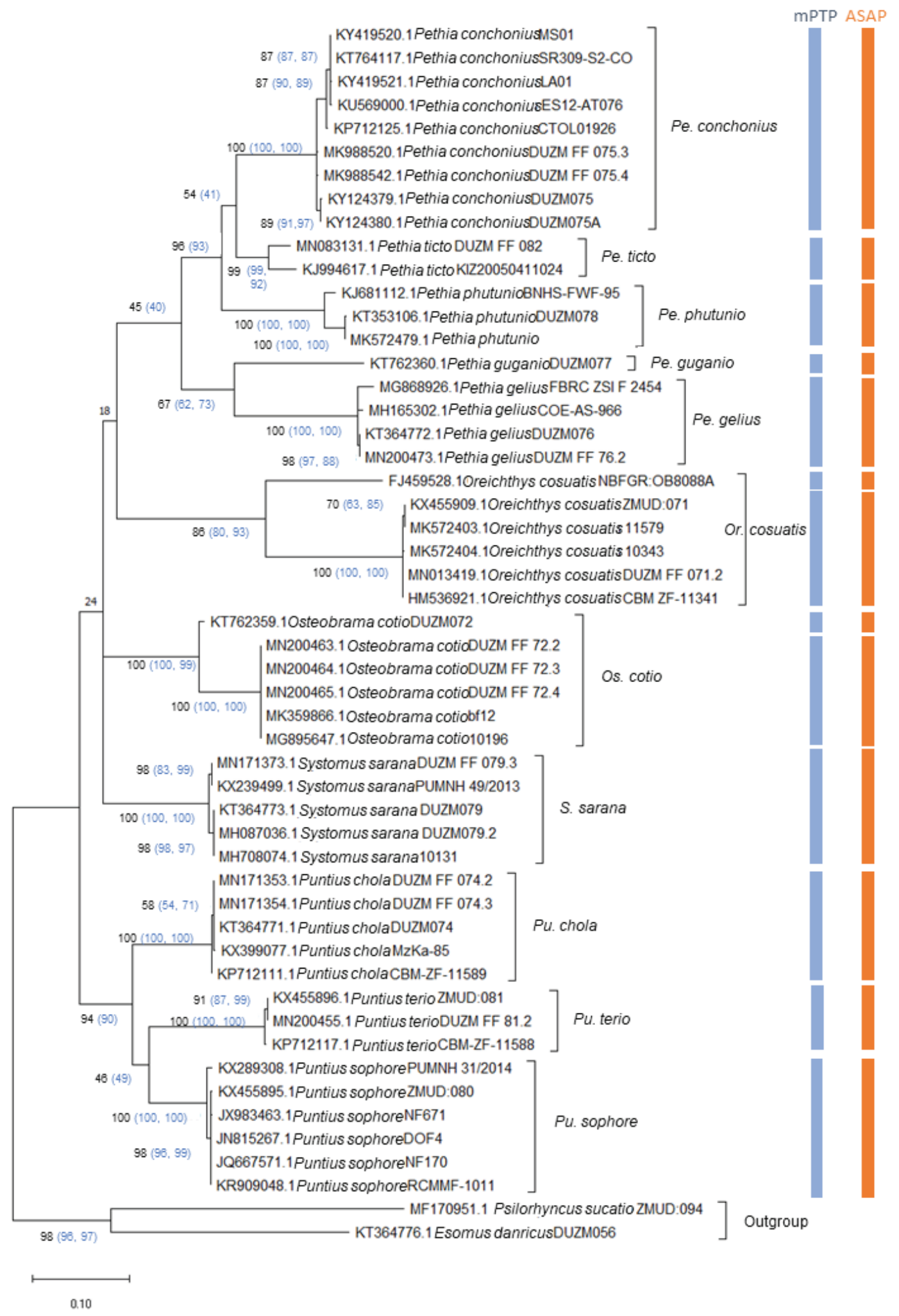

Figure 4. Summary of results obtained through different analyses of eleven smiliogastrin fishes. On the left: Molecular phylogenetic analysis generated from COI gene sequences employing the maximum likelihood method. The evolutionary analyses were conducted with 1000 bootstrap replicates (values are indicated next to the branches). The values in blue color inside brackets are the bootstrap values from the neighbor-joining and maximum parsimony methods. Sequences of the present study are designated as DUZM and ZMUD. On the right: Species delimitation analysis using mPTP and ASAP. The unique partition predicted by mPTP (blue vertical bars) and the partition with the "best" ASAP-score (2.50) using the K80 substitution model (orange vertical bars) are shown. Proba (probability that the partition at step $\mathrm{n}$ is different from the partition at step $\mathrm{n}-1)=1.39 \mathrm{e}-03$, barcode gap width $=7.93 \mathrm{e}-03$. nb (number of species as identified by ASAP in the corresponding partition) groups $=13$. 
three specimens of Os. cotio amassed from Boiddar Bazar Ghat. However, not unlike the previous findings (Rahman et al. 2018) on specimens collected from different rivers of India and Bangladesh, we observed no distinct morphological difference among the Osteobrama species allowing their separation at sub-species level or their representation as different species, which contradicts the proposition put forward by Singh et al. (2018). Furthermore, an in-depth study with a larger sample size can solve the conundrum of this cryptic species.

In conclusion, the results of morphometric, meristic, and molecular analyses of Smiliogastrinae species of Bangladesh that were carried out in the present study were consistent, thus validating the COI barcode's effectiveness in accurately discriminating the species. Nevertheless, the low bootstrap value or the weakly supported nodes can be explained by the small sample size, which could be resolved if there were more ingroups and samples from closely related genera of the same family. The resulting phylogenetic trees from the analyses were largely congruent and revealed the same pattern of clustering for the studied populations with slightly different tree topologies, which differ only at weakly supported internal nodes (Figure 4). However, similarly to the previous studies (Tan and Armbruster 2018), we would like to stress the need for the further taxonomic revision of the Cyprinidae family so as to solve the conundrum of the cryptic species. More importantly, the frightening decline of barbs, especially the disappearance of Pu. puntio, Pe. gelius, Pe. guganio and $P e$. ticto from natural habitats zeroes in on the need to introduce conservation measures for these species immediately, before they become locally extinct.

\section{ACKNOWLEDGMENTS}

This work was supported by a Competitive Research Grant (Grant no. CRG 471) to the first author through the National Agricultural Technology Program-Phase II Project from Bangladesh Agricultural Research Council Dhaka, Bangladesh. We are thankful to Mr. Abu Obaida for his support during sample collection. Our sincere thanks are due to the two anonymous reviewers for their critical review, thoughtful comments and advice which helped to improve the earlier version of the manuscript.

\section{CONFLICTS OF INTEREST}

The authors declare that they have no conflicts of interest.

\section{DATA AVAILABILITY STATEMENT}

The sequence data have been submitted to the NCBI GenBank database (https://www.ncbi.nlm.nih.gov/genbank/) under the accession numbers KX455895-96, KX455909, KY124379-80, KT353106, KT364771-73, KT762359-60, MH087036, MK988520, MK988542, MN013419, MN083131, MN171353-54, MN171373, MN200455, MN200463-65, MN200473 which have open public access.

\section{REFERENCES}

Ahmed, M. S., M. M. K. Chowdhury, and L. Nahar. 2019. Molecular characterization of small indigenous fish species (SIS) of Bangladesh through DNA barcodes. Gene 684: 53-57. https://doi.org/10.1016/j. gene. 2018.10 .048

Ahmed, M. S., S. K. Datta, and A. A. Zhilik. 2020. Molecular diversity of freshwater fishes of Bangladesh assessed by DNA barcoding. Bangladesh Journal of Zoology 48 (1): 1-19.

Banglapedia 2015. National Encyclopaedia of Bangladesh. http://en.banglapedia.org/index.php/Barb

Brower, A. V. Z. 2006. Problems with DNA barcodes for species delimitation: 'ten species' of Astraptes fulgerator reassessed (Lepidoptera: Hesperiidae). Systematics and Biodiversity 4: 127-132.

Collins, R. A., and R. H. Cruickshank. 2013. The seven deadly sins of DNA barcoding. Molecular Ecology Resources 13 (6): 969-75. doi: 10.1111/1755-0998.12046. Epub 2012 Dec 27. PMID: 23280099.

Dasmahapatra, K. K., M. Elias, R. I. Hill, J. I. Hoffman, and J. Mallet. 2010. Mitochondrial DNA barcoding detects some species that are real, and some that are not. Molecular Ecology Resources 10: 264-273.

Down, T. R., and W. W. Wilfinger. 1983. Fluorometric Quantification of DNA in Cells and Tissue. Analytical Biochemistry 131: 538-547.

Dupuis, J. R., A. D. Roe, and F. A. H. Sperling. 2012. Multilocus species delimitation in closely related animals and fungi: one marker is not enough. Molecular Ecology 21: 4422-4436.

Edgar, R. C. 2010. Quality measures for protein alignment benchmarks. Nucleic Acids Research 38 (7): 21452153. https://doi.org/10.1093/nar/gkp1196

Frézal, L., and R. Leblois. 2008. Four years of DNA barcoding: current advances and prospects. Infection, Genetics and Evolution, Elsevier 8 (5): 727-736. https://doi. org/10.1016/j.meegid.2008.05.005ï

Fujita, M. K., A. D. Leache, F. T. Burbrink, J. A. McGuire, and C. Moritz. 2012. Coalescent-based species delimitation in an integrative taxonomy. Trends in Ecology and Evolution 27: 480-488. 
Haroon, A., G. Halder, S. Rahman, M. Razzaque, M. Alam, and S. Amin. 2002. Sylhet-Mymensingh basin fish stock assessment. Final Report 81. Chandpur, Bangladesh: Bangladesh Fisheries Research Institute, Riverine Station.

Hasegawa, M., H. Kishino, and T.-A. Yano. 1985. Dating of the Human-Ape splitting by a Molecular Clock of Mitochondrial DNA. Molecular Evolution 22: 160-174.

Hebert, P. D. N., A. Cywinska, S. L. Ball, and J. R. DeWaard. 2003. Biological identifications through DNA barcodes. Proceedings of the Royal Society B: Biological Sciences 270 (1512): 313-321. https://doi.org/10.1098/ rspb. 2002.2218

Hillis, D. M., and J. J. Bull. 1993. Empirical test of bootstrapping as a method for assessing confidence in phylogenetic analysis. Systematic Biology 42 (2): 182-192. https://academic.oup.com/sysbio/article abstract/42/2/ 182/1730933?redirectedFrom=fulltext

Hossain, M. E., M. M. Chowdhury, and K. F. Iqbal. 2008. A Survey on the faunal diversity of Savar Upazilla, Dhaka, Bangladesh. Pakistan Journal of Biological Sciences 11 (3): 373-379.

Huang, X., and A. Madan. 1999. CAP3: A DNA sequence assembly program. Genome Research 9: 868-877. www.genome.orgIUCN

IUCN Bangladesh. 2015. Red list of Bangladesh: Freshwater Fishes (Vol. 5). International Union for Conservation of Nature and Natural Resources, IUCN Bangladesh Country Office.

Kapli, P., S. Lutteropp, J. Zhang, K. Kobert, P. Pavlidis, A. Stamatakis, and T. Flouri. 2017. Multi-rate Poisson tree processes for single-locus species delimitation under maximum likelihood and Markov chain Monte Carlo. Bioinformatics 33: 1630-1638.

Kimura, M. 1980. A simple method for estimating evolutionary rates of base substitutions through comparative studies of nucleotide sequences. Molecular Evolution 16: 111-120.

Kumar, S., G. Stecher, M. Li, C. Knyaz, and K. Tamura. 2018. MEGAX: Molecular evolutionary genetics analysis across computing platforms. Molecular Biology and Evolution 35 (6): 1547-1549. https://doi.org/10.1093/ molbev/msy096

Lecointre, G., H. Philippe, H. L. Vân Lê, and H. le Guyader. 1994. How many nucleotides are required to resolve a phylogenetic problem? The use of a new statistical method applicable to available sequences. Molecular Phylogenetics and Evolution 3 (4): 292-309. https:// doi.org/10.1006/mpev.1994.1037

Leray, M., and N. Knowlton. 2015. DNA barcoding and metabarcoding of standardized samples reveal patterns of marine benthic diversity. PNAS 112 (7): 2076-2081. https://doi.org/10.5883/DS-ARMS

Mian, S., M. J. Ferdous, M. Y. Sarker, M. J. Islam, A. M. Reza, M. M. Iqbal, and M. A. R. Hossain. 2013.
Status of biodiversity and conservation of freshwater barbs in Bangladesh. World Journal of Fish and Marine Sciences 5 (6): 701-708. https://doi.org/10.5829/idosi. wjfms.2013.05.06.7665

Mohsin, A. B. M., S. M. M. Haque, S. M. Galib, M. F. H. Fahad, N. Chaki, M. N. Islam, and M. M. Rahman. 2013. Seasonal abundance of fin fishes in the Padma river at Rajshahi district, Bangladesh. World Journal of Fish and Marine Sciences 5 (6): 680-685. https://doi. org/10.5829/idosi.wjfms.2013.05.06.75109

Nei, M., and S. Kumar. 2000. Molecular Evolution and Phylogenetics. Oxford university press.

Puillandre, N., S. Brouillet, and G. Achaz. 2020. ASAP: Assemble Species by Automatic Partitioning. Molecular Ecology Resources 21 (7). DOI: 10.1111/17550998.13281.

Rahman, A. K. A. 2005. Freshwater fishes of Bangladesh (2nd ed.). Dhaka 1000: Zoological Society of Bangladesh, Department of Zoology, University of Dhaka.

Rahman, M. M., M. Norén, A. R. Mollah, and S. Kullander. 2018. The identity of Osteobrama cotio, and the status of "Osteobrama serrata" (Teleostei: Cyprinidae: Cyprininae). Zootaxa 4504 (1): 105-118. https://doi. org/10.11646/zootaxa.4504.1.5

Roos, N., M. A. Wahab, M. A. R. Hossain, and S. H. Thilsted. 2007. Linking human nutrition and fisheries: Incorporating micronutrient-dense, small indigenous fish species in carp polyculture production in Bangladesh. Food and Nutrition Bulletin 28 (2 Suppl.), S280-S293. https://doi.org/10.1177/15648265070282s207

Rubinoff, D., S. Cameron, and K. Will. 2006. A genomic perspective on the shortcomings of mitochondrial DNA for 'barcoding' identification. Journal of Heredity 97: 581-594.

Sambrook, J. F., E. F. Fritsch, and T. Maniatis. 1989. Molecular Cloning: A Laboratory Manual (2nd ed., Issue Ed. 2). Cold Spring Harbor, USA: Cold Spring Harbor Laboratory Press.

Siddiqui, K. U., M. A. Islam, S. M. H. Kabir, M. Ahmad, A. T. A. Ahmed, A. K. A. Rahman, E. U. Haque, Z. U. Ahmed, Z. N. T. Begum, M. A. Hasan, M. Khondker, and M. M. Rahman. 2007. Encyclopedia of Flora and Fauna of Bangladesh (Vol. 23). Asiatic Society of Bangladesh.

Singh, M., R. Verma, R. Yumnam, and W. Vishwanath. 2018. Molecular phylogenetic analysis of genus Osteobrama Heckel, 1843 and discovery of Osteobrama serrata sp. nov. from North East India. Mitochondrial DNA Part A: DNA Mapping, Sequencing, and Analysis 29 (3): 361-366. https://doi.org/10.1080/24701394.201 7.1285289

Talwar, P. K., and A. G. Jhingran. 1991. Inland Fishes of India and Adjacent Countries (Vols. 1-2). Oxford-IBH Publishing Co. Pvt. Ltd.

Tamura, K., M. Nei, and S. Kumar. 2004. Prospects for infer- 
ring very large phylogenies by using the neighbor-joining method. Proceedings of the National Academy of Sciences of the United States of America 101 (30): 11030-11035. https://doi.org/10.1073/pnas.0404206101

Tan, M., and J. W. Armbruster. 2018. Phylogenetic classification of extant genera of fishes of the order Cypriniformes (Teleostei: Ostariophysi). Zootaxa 4476 (1): 6-39. https://doi.org/10.11646/zootaxa.4476.1.4

Tsigenopoulos, C. S., and P. Berrebi. 2000. Molecular phylogeny of north Mediterranean freshwater barbs (genus Barbus: Cyprinidae) inferred from cytochrome b sequences: Biogeographic and systematic implications. Molecular Phylogenetics and Evolution 14 (2): 165-179. https://doi.org/10.1006/mpev.1999.0702

Ward, R. D., T. S. Zemlak, B. H. Innes, P. R. Last, and P. D. N. Hebert. 2005. DNA barcoding Australia's fish species. Philosophical Transactions of the Royal Society B: Biological Sciences 360 (1462): 1847-1857.
https://doi.org/10.1098/rstb.2005.1716Xia, X. 2017. DAMBE6: New tools for microbial genomics, phylogenetics, and molecular evolution. Journal of Heredity 108 (4): 431-437. https://doi.org/10.1093/JHERED/ ESX033

Yang, L., T. Sado, M. Vincent Hirt, E. Pasco-Viel, M. Arunachalam, J. Li, X. Wang, J. Freyhof, K. Saitoh, A. M. Simons, M. Miya, S. He, and R. L. Mayden. 2015. Phylogeny and polyploidy: Resolving the classification of cyprinine fishes (Teleostei: Cypriniformes). Molecular Phylogenetics and Evolution 85: 97-116. https://doi.org/10.1016/j.ympev.2015.01.014

Zharkikh, A., and W. Li. 1992. Statistical properties of bootstrap estimation of phylogenetic variability from nucleotide sequences. I. Four taxa with a molecular clock. Molecular Biology and Evolution 9 (6). https:// doi.org/10.1093/oxfordjournals.molbev.a040782 GenBank https:/www.ncbi.nlm.nih.gov/genbank/

Supplementary Table 1. Analysis of nucleotide compositions for the obtained mitochondrial COI gene length of the species explored in this study.

\begin{tabular}{|c|c|c|c|c|c|c|c|c|}
\hline \multirow{2}{*}{ Species } & \multirow{2}{*}{ Accession no. } & \multirow{2}{*}{$\begin{array}{c}\text { Length of } \\
\text { obtained } \\
\text { sequence (bp) }\end{array}$} & \multicolumn{6}{|c|}{ Base composition (\%) } \\
\hline & & & $\mathrm{T}$ & $\mathrm{C}$ & A & G & AT & GC \\
\hline Pu. sophore & KX455895.1 & 675 & 29.78 & 25.63 & 27.56 & 17.04 & 57.33 & 42.67 \\
\hline \multirow[t]{3}{*}{ Pu. chola } & KT364771.1 & 668 & 27.40 & 27.54 & 26.65 & 18.41 & 54.04 & 45.96 \\
\hline & MN171353.1 & 614 & 27.36 & 28.18 & 26.55 & 17.92 & 53.91 & 46.09 \\
\hline & MN171354.1 & 617 & 27.23 & 28.04 & 26.74 & 17.99 & 53.97 & 46.03 \\
\hline \multirow[t]{2}{*}{ Pu. terio } & KX455896.1 & 671 & 29.96 & 25.04 & 27.12 & 17.88 & 57.08 & 42.92 \\
\hline & MN200455.1 & 604 & 30.79 & 24.67 & 27.32 & 17.22 & 58.11 & 41.89 \\
\hline \multirow[t]{4}{*}{ Pe. conchonius } & KY124379.1 & 634 & 28.71 & 26.34 & 26.34 & 18.61 & 55.05 & 44.95 \\
\hline & KY124380.1 & 643 & 29.08 & 26.59 & 25.82 & 18.51 & 54.90 & 45.10 \\
\hline & MK988520.1 & 620 & 28.87 & 27.10 & 26.45 & 17.58 & 55.32 & 44.68 \\
\hline & MK988542.1 & 622 & 28.78 & 27.01 & 26.21 & 18.01 & 54.98 & 45.02 \\
\hline \multirow[t]{2}{*}{ Pe.gelius } & KT364772.1 & 668 & 29.34 & 26.50 & 25.60 & 18.56 & 54.94 & 45.06 \\
\hline & MN200473.1 & 607 & 29.65 & 26.69 & 25.86 & 17.79 & 55.52 & 44.48 \\
\hline Pe.phutunio & KT353106.1 & 669 & 28.85 & 26.16 & 25.86 & 19.13 & 54.71 & 45.29 \\
\hline Pe. guganio & KT762360.1 & 669 & 29.00 & 26.31 & 26.16 & 18.54 & 56.44 & 43.56 \\
\hline Pe. ticto & MN083131.1 & 566 & 30.74 & 24.56 & 28.98 & 15.72 & 59.72 & 40.28 \\
\hline \multirow[t]{3}{*}{ S. sarana } & KT364773.1 & 668 & 28.29 & 26.50 & 28.14 & 17.07 & 56.49 & 43.51 \\
\hline & MH087036.1 & 655 & 28.55 & 26.56 & 27.94 & 16.95 & 56.86 & 43.14 \\
\hline & MN171373.1 & 612 & 28.27 & 26.80 & 28.59 & 16.34 & 55.16 & 44.84 \\
\hline \multirow[t]{2}{*}{ O. cosuatis } & KX455909.1 & 675 & 30.96 & 26.22 & 26.96 & 15.85 & 57.93 & 42.07 \\
\hline & MN013419.1 & 624 & 31.41 & 26.28 & 26.92 & 15.38 & 58.33 & 41.67 \\
\hline \multirow[t]{4}{*}{ O. cotio } & KT762359.1 & 669 & 27.65 & 27.20 & 27.95 & 17.19 & 55.61 & 44.39 \\
\hline & MN200463.1 & 605 & 27.93 & 27.27 & 27.77 & 17.02 & 55.70 & 44.30 \\
\hline & MN200464.1 & 607 & 27.84 & 27.18 & 28.01 & 16.97 & 55.85 & 44.15 \\
\hline & MN200465.1 & 605 & 27.93 & 27.27 & 27.77 & 17.02 & 55.70 & 44.30 \\
\hline $\begin{array}{l}\text { Average } \\
\pm \mathrm{SD}\end{array}$ & & 636 & $\begin{array}{c}28.93 \\
\pm 0.55\end{array}$ & $\begin{array}{c}26.57 \\
\pm 0.66\end{array}$ & $\begin{array}{c}27.04 \\
\pm 1.01\end{array}$ & $\begin{array}{r}17.46 \\
\pm 1.12\end{array}$ & $\begin{array}{c}55.97 \\
\pm 1.50\end{array}$ & $\begin{array}{r}44.03 \\
\pm 1.50\end{array}$ \\
\hline
\end{tabular}


Supplementary Table 2. Information about ingroup and outgroup sequences utilized for the phylogenetic analysis in the study.

\begin{tabular}{|c|c|c|c|}
\hline Species & $\begin{array}{c}\text { GenBank } \\
\text { Accession No. }\end{array}$ & Country of Origin & Author/ Reference \\
\hline \multirow{5}{*}{$\begin{array}{l}\text { Pe. } \\
\text { conchonius }\end{array}$} & KP712125.1 & $\begin{array}{l}\text { India: Market between } \\
\text { Kolkata and Basirhat, } \\
\text { North } 24 \text { Parganas, } \\
\text { West Bengal }\end{array}$ & $\begin{array}{l}\text { Yang, L., T. Sado, M. Vincent Hirt, E. Pasco-Viel, M. Arunachalam, } \\
\text { J. Li, X. Wang, J. Freyhof, K. Saitoh, A. M. Simons, M. Miya, S. He, } \\
\text { and R. L. Mayden. 2015. Phylogeny and polyploidy: Resolving the } \\
\text { classification of cyprinine fishes (Teleostei: Cypriniformes). Molecu- } \\
\text { lar Phylogenetics and Evolution 85: } 97-116 \text {. } \\
\text { https:doi.org/10.1016/j.ympev.2015.01.014 }\end{array}$ \\
\hline & KY419520.1 & \multirow{2}{*}{ India: Tamilnadu } & \multirow{2}{*}{$\begin{array}{l}\text { Direct Submission by Rajasekaran, N., S. Chandrasekar, and } \\
\text { R. Sivakumar, Molecular identification of Pethia conchonius from } \\
\text { South Indian rivers (Unpublished) }\end{array}$} \\
\hline & KY419521.1 & & \\
\hline & KT764117.1 & India: Tamilnadu & $\begin{array}{l}\text { Direct Submission by Sabaridasan, A., and R. Soranam (Unpub- } \\
\text { lished) }\end{array}$ \\
\hline & KU569000.1 & $\begin{array}{l}\text { South Africa: } \\
\text { Tyger, Cape Town, } \\
\text { Western Cape }\end{array}$ & $\begin{array}{l}\text { van der Walt, K. A., T. Mäkinen, E. R. Swartz, and O. Weyl. } 2017 . \\
\text { DNA barcoding of South Africa's ornamental freshwater fish-are the } \\
\text { names reliable? African Journal of Aquatic Science } 42 \text { (2). } \\
\text { https://doi.org/10.2989/16085914.2017.1343178 }\end{array}$ \\
\hline \multirow[t]{2}{*}{ Pe.phutunio } & KJ681112.1 & $\begin{array}{l}\text { India: Sambalpur, } \\
\text { Odisha }\end{array}$ & $\begin{array}{l}\text { Katwate, U., C. Katwate, R. Raghavan, M. S. Paingankar, and } \\
\text { N. Dahanukar. 2014. Pethia lutea, a new species of barb (Teleostei: } \\
\text { Cyprinidae) and new records of P. punctata from northern Western } \\
\text { Ghats of India. Journal of Threatened Taxa } 6 \text { (6): 5797-5818. } \\
\text { https://doi.org/10.11609/jott.03929.5797-818 }\end{array}$ \\
\hline & MK572479.1 & $\begin{array}{l}\text { Bangladesh: Hakaluki } \\
\text { Haor in Borolek, } \\
\text { Moulvibazar, Sylhet }\end{array}$ & $\begin{array}{l}\text { Rahman, M. M., M. Norén, A. R., Mollah, and S. O. Kullander. } \\
\text { 2019. Building a DNA barcode library for the freshwater fishes of } \\
\text { Bangladesh. Scientific Reports } 9 \text { (1). } \\
\text { https://doi.org/10.1038/s41598-019-45379-6 }\end{array}$ \\
\hline \multirow[b]{2}{*}{ Pe.gelius } & MH165302.1 & India: Agartala, Tripura & $\begin{array}{l}\text { Direct Submission by Parhi, J., N. Chaoba Devi, H. Priyadarshi, } \\
\text { P. Biswas, and P. K. Pandey. }\end{array}$ \\
\hline & MG868926.1 & N/A & $\begin{array}{l}\text { Direct Submission by Laskar, B. A., A. Harikumar, S. Mandal, } \\
\text { S. Rehanuma, and A. D. Narahari. J. DNA Barcoding of Eastern } \\
\text { Ghats Fauna (Unpublished) }\end{array}$ \\
\hline Pe. ticto & KJ994617.1 & China & $\begin{array}{l}\text { Zheng, L. P., J. X. Yang, and X. Y. Chen. 2016. Molecular phylogeny } \\
\text { and systematics of the Barbinae (Teleostei: Cyprinidae) in China } \\
\text { inferred from mitochondrial DNA sequences. Biochemical Systematics } \\
\text { and Ecology 68: } 250-259 \text {. } \\
\text { https://doi.org/10.1016/j.bse.2016.07.012 }\end{array}$ \\
\hline \multirow{5}{*}{ Pu. sophore } & JQ667571.1 & $\begin{array}{l}\text { India: Anchinal River, } \\
\text { Harda, Madhya } \\
\text { Pradesh }\end{array}$ & $\begin{array}{l}\text { Khedkar, G. D., R. A. Jamdade, R. H. Hanner, and P. D. N. Hebert. } \\
\text { DNA Barcoding can Help Ornamental Fish Trading in Changing } \\
\text { Regime of Indian Biodiversity Act (Unpublished) }\end{array}$ \\
\hline & JX983463.1 & $\begin{array}{l}\text { India: Narmada ghat, } \\
\text { Narmada River, } \\
\text { Hoshangabad, } \\
\text { Madhya Pradesh } \\
\end{array}$ & $\begin{array}{l}\text { Khedkar, G. D., R. Jamdade, S. Naik, L. David, and D. Haymer. } \\
\text { 2014. DNA barcodes for the Fishes of the Narmada, India's longest } \\
\text { rivers. PLoS ONE } 9 \text { (7). } \\
\text { https://doi.org/10.1371/journal.pone. } 0101460\end{array}$ \\
\hline & JN815267.1 & India & $\begin{array}{l}\text { Dhar, B., and S. Ghosh. 2015. Genetic assessment of ornamental fish } \\
\text { species from North East India. Gene } 555 \text { (2): 382-392. } \\
\text { https://doi.org/10.1016/j.gene.2014.11.037 }\end{array}$ \\
\hline & KR909048.1 & India: Manipur & $\begin{array}{l}\text { Direct Submission by D. N. Sobita, and D. C. Basudha. Taxo- } \\
\text { nomic relationship of some cyprinid fishes of Manipur, India } \\
\text { (Unpublished) }\end{array}$ \\
\hline & KX289308.1 & India & $\begin{array}{l}\text { Raja, M., and P. Peruma. 2017. DNA barcoding and phylogenetic } \\
\text { relationships of selected South Indian freshwater fishes based on } \\
\text { mtDNA COI sequences. Journal of Phylogenetics \& Evolutionary } \\
\text { Biology } 5 \text { (184). } \\
\text { https://doi.org/10.4172/2329-9002.1000184 }\end{array}$ \\
\hline Pu. chola & KX399077.1 & India & $\begin{array}{l}\text { Barman, A. S., M. Singh, and P. K. Pandey. 2018. DNA barcoding } \\
\text { and genetic diversity analyses of fishes of Kaladan River of Indo- } \\
\text { Myanmar biodiversity hotspot. Mitochondrial DNA Part A: DNA } \\
\text { Mapping, Sequencing, and Analysis } 29 \text { (3): 367-378. } \\
\text { doi:10.1080/24701394.2017.1285290 }\end{array}$ \\
\hline
\end{tabular}




\begin{tabular}{|c|c|c|c|}
\hline Species & $\begin{array}{c}\text { GenBank } \\
\text { Accession No. }\end{array}$ & Country of Origin & Author/ Reference \\
\hline Pu. terio & KP712117.1 & $\begin{array}{l}\text { India: Jagatpur Market, } \\
\text { Kolkata, West Bengal }\end{array}$ & $\begin{array}{l}\text { Yang, L., T. Sado, M. Vincent Hirt, E. Pasco-Viel, M. Arunachalam, } \\
\text { J. Li, X. Wang, J. Freyhof, K. Saitoh, A. M. Simons, M. Miya, S. He, } \\
\text { and R. L. Mayden. 2015. Phylogeny and polyploidy: Resolving } \\
\text { the classification of cyprinine fishes (Teleostei: Cypriniformes). } \\
\text { Molecular Phylogenetics and Evolution 85: 97-116. } \\
\text { https://doi.org/10.1016/j.ympev.2015.01.014. }\end{array}$ \\
\hline \multirow[t]{2}{*}{ S. sarana } & KX239499.1 & India & $\begin{array}{l}\text { Raja, M., and P. Perumal. 2017. DNA barcoding and phylogenetic } \\
\text { relationships of selected South Indian freshwater fishes based on } \\
\text { mtDNA COI sequences. Journal of Phylogenetics \& Evolutionary } \\
\text { Biology } 5 \text { (184). } \\
\text { https://doi.org/10.4172/2329-9002.1000184 }\end{array}$ \\
\hline & MH708074.1 & $\begin{array}{l}\text { Bangladesh: Pyiang } \\
\text { River at Jaflong, about } \\
60 \mathrm{~km} \text { from Sylhet city }\end{array}$ & $\begin{array}{l}\text { Rahman, M. M., M. Norén, A. R. Mollah, and S. Kullander. 2018. The } \\
\text { identity of Osteobrama cotio, and the status of "Osteobrama serrata" } \\
\text { (Teleostei: Cyprinidae: Cyprininae). Zootaxa } 4504 \text { (1): 105-118. } \\
\text { https://doi.org/10.11646/zootaxa.4504.1.5 }\end{array}$ \\
\hline \multirow{4}{*}{ Or. cosuatis } & HM536921.1 & India & $\begin{array}{l}\text { Yang, L., R. L. Mayden, T. Sado, S. He, K. Saitoh, and M. Miya. } \\
\text { 2010. Molecular phylogeny of the fishes traditionally referred to } \\
\text { Cyprinini sensu stricto (Teleostei: Cypriniformes). Zoologica Scripta } \\
39 \text { (6): } 527-550 \text {. } \\
\text { https://oi.org/10.1111/j.1463-6409.2010.00443.x }\end{array}$ \\
\hline & MK572403.1 & $\begin{array}{l}\text { Bangladesh: Surma } \\
\text { River left bank, at } \\
\text { Kheaghat point, } \\
1.5 \mathrm{~km} \text { upstream } \\
\text { from Golapganj, Sylhet }\end{array}$ & $\begin{array}{l}\text { Rahman, M. M., M. Norén, A. R. Mollah, and S. O. Kullander. } \\
\text { 2019. Building a DNA barcode library for the freshwater fishes of } \\
\text { Bangladesh. Scientific Reports } 9 \text { (1). } \\
\text { https://doi.org/10.1038/s41598-019-45379-6 }\end{array}$ \\
\hline & MK572404.1 & $\begin{array}{l}\text { Bangladesh: } \\
\text { Padma River near } \\
\text { Srinagar, Dhaka }\end{array}$ & $\begin{array}{l}\text { Rahman, M. M., M. Norén, A. R. Mollah, and S. O. Kullander. } \\
\text { 2019. Building a DNA barcode library for the freshwater fishes of } \\
\text { Bangladesh. Scientific Reports } 9 \text { (1). } \\
\text { https://doi.org/10.1038/s41598-019-45379-6 }\end{array}$ \\
\hline & FJ459528.1 $1^{\ddagger}$ & India: Assam & $\begin{array}{l}\text { Lakra, W. S., M. Singh, M. Goswami, A. Gopalakrishnan, K. K. Lal, } \\
\text { V. Mohindra, U. K. Sarkar, P. P. Punia, K. v. Singh, J. P. Bhatt, } \\
\text { and S. Ayyappan. 2016. DNA barcoding Indian freshwater fishes. } \\
\text { Mitochondrial DNA Part A: DNA Mapping, Sequencing, and Analysis } \\
27 \text { (6): 4510- 4517. } \\
\text { https://doi.org/10.3109/19401736.2015.1101540 }\end{array}$ \\
\hline \multirow[b]{2}{*}{ Os. cotio } & MK359866.1 & $\begin{array}{l}\text { Republic of Korea: } \\
\text { Busan }\end{array}$ & $\begin{array}{l}\text { Direct Submission by Alam, M. J., S. Andriyono, S. P. Sektiana, } \\
\text { A. Eunus, and H. -W. Kim. }\end{array}$ \\
\hline & MG895647.1 & $\begin{array}{l}\text { Bangladesh: Town fish } \\
\text { market (Principally } \\
\text { from Kaptai Lake), } \\
\text { Rangamati, Chittagong }\end{array}$ & $\begin{array}{l}\text { Rahman, M. M., M. Norén, A. R. Mollah, and S. Kullander. 2018. The } \\
\text { identity of Osteobrama cotio, and the status of "Osteobrama serrata" } \\
\text { (Teleostei: Cyprinidae: Cyprininae). Zootaxa } 4504 \text { (1): 105-118. } \\
\text { https://doi.org/10.11646/zootaxa.4504.1.5 }\end{array}$ \\
\hline $\begin{array}{l}\text { Psilorhynchus } \\
\text { sucatio }\end{array}$ & MF170951.1 & $\begin{array}{l}\text { Bangladesh: } \\
\text { Chittagong University }\end{array}$ & $\begin{array}{l}\text { Ahmed, M. S., M. M. K. Chowdhury, and L. Nahar. 2019. Molecular } \\
\text { characterization of small indigenous fish species (SIS) of Bangladesh } \\
\text { through DNA barcodes. Gene } 684: 53-57 \text {. } \\
\text { https://doi.org/10.1016/j.gene.2018.10.048 }\end{array}$ \\
\hline $\begin{array}{l}\text { Esomus } \\
\text { danricus }\end{array}$ & KT364776.1 & $\begin{array}{l}\text { Bangladesh: Tanguar } \\
\text { Haor, Sunamganj }\end{array}$ & $\begin{array}{l}\text { Ahmed, M. S., M. M. K. Chowdhury, and L. Nahar. 2019. Molecular } \\
\text { characterization of small indigenous fish species (SIS) of Bangladesh } \\
\text { through DNA barcodes. Gene 684: 53-57. } \\
\text { https://doi.org/10.1016/j.gene.2018.10.048 }\end{array}$ \\
\hline
\end{tabular}

$\Phi=$ Outgroup,$\neq=$ Cryptic species. 